\section{Jeferson Tenório}

\author{
Nasceu no Rio de Janeiro, em 1977. Radicado \\ em Porto Alegre é mestre em Letras pela \\ Universidade Federal do Rio Grande do Sul. \\ Premiado no concurso Paulo Leminski em 2009, \\ com o conto "Cavalos não choram". Outro \\ conto, "A beleza e a tristeza", foi adaptado para \\ o teatro em 2007 e 2008. É autor do romance \\ $O$ beijo na parede, premiado como livro do \\ ano de 2014 pela AGES (Associação Gaúcha de \\ Escritores). Em 2017, teve textos traduzidos \\ para o espanhol pela Revista uruguaia Pontis. \\ Atualmente trabalha na finalização do próximo \\ romance Estela sem Deus.
}

\section{treinamento}

A avó de Estela costumava dizer que cada um já nasce com algum problema pra resolver, um problema que dura a vida toda. Estela tinha um: não sabia lidar com a perda. Há pessoas que já nascem perdendo na vida, ela pensou um dia. Foi o caso do pai, que resolveu ser cantor e não sabia nada de finanças e por isso sempre reclamava da falta de dinheiro. No entanto, a mãe de Estela achava que a solução era ignorar que eles faziam parte do grupo dos vencidos. Assim, era mais fácil suportar a vida que levavam. Foi nesse tempo que Estela passou a treinar o abandono. O treino era um modo de suportar a tristeza. Tudo começou com um casal de peixinhos que ela tinha no quarto. O Ari e a Elizete. Os dois eram da raça "gup", pequenos e todo colorido. Não ficavam num aquário porque era caro. Ficavam num pote comum de maionese. Um dia a Elizete apareceu boiando e aquela morte inesperada despertou a fragilidade em Estela. A partir dali, a menina entendeu que a morte dos peixes era igual a morte das pessoas. E, assim, teria de aceitar o desaparecimento brutal dos seres. Primeiro, ficou observando por algum tempo a Elizete boiando e o irmão mais velho disse que ela tinha de tirá-lo dali e enterrá-lo. Mas Estela não teve coragem de enterrar a Elizete. Pediu para o irmão Augusto fazê-lo. Não soube se ele fez. Mas desconfiava que o irmão tenha cumprido o pedido.Talvez tenha pensando na tristeza que era aquilo: um peixe que poderia ter o mar como casa e no fim acabaria a vida num pote de maionese. No quarto, ao perceber a solidão do outro peixe, Estela achou que ele morreria em breve. E como num estalo, Estela pensou: preciso me proteger disso. Desde aquele momento, o desaparecimento tornou-se um perigo constante. Passou algumas noites dormindo pouco, estava preocupada com a morte. No meio da madrugada, levantava para ver se o peixe estava vivo. Deixava a luz acesa como se escuridão pudesse acelerar o fim. Mas um dia, ao acordar, pensou outra vez: a morte não vai mais me pegar de surpresa. Logo encontrou uma solução; era preciso treinar o abandono. Exercitar a despedida. Inverteria a lógica da dor. E a primeira coisa que fez foi retirar o peixe do quarto. Ari passou a dormir em cima da mesa da cozinha. À noite, na cama, olhando para o teto, Estela fingia que o peixe já havia morrido. E era isso que a confortava: antecipar a morte. Sem saber, a menina invertia o futuro. Desarrumava os fatos dentro de si. Às vezes, doía saber que ele estava lá, ao seu alcance, mas não ia buscá-lo. Brincava de doer. Acostumou-se com desaparecimento. Estela se agarrava ao precário e, desse modo, aceitava com serenidade o fim das coisas.

No entanto, o peixe morreu dias depois. E para decepção de Estela a dor foi a mesma, senão mais intensa. Depois sentiu raiva de si mesma. Não se controla o fim, ela pensou. Dessa vez, o irmão disse que não ia se meter nisso, além de achar aquilo uma grande bobagem e que o pai me disse que temos de gastar lágrimas é com gente, e não com os peixes. Estela 


\section{Opiniães}

quis retrucar, mas apenas pensou: os peixes às vezes parecem melhores que as pessoas.

Estela foi enterrar o peixe. Cuidou da morte sozinha. Cavou uma pequena cova. Colocou o Ari ali dentro. Rezou um Pai Nosso. Preferiu pensar que agora a terra seria o mar daquele peixe. A nova morada. Olhou ao redor e percebeu que o quintal não era tão ruim. Imaginou que assim que virasse as costas o Ari começaria a nadar por debaixo da terra. E depois, quando se levantou, Estela chorou. Após o enterro, rezou para Deus pedindo que o peixinho virasse um santo, porque os santos são seres que já conheceram a morte, mas que gostaram tanto da vida que ainda permaneciam entre os vivos, ela pensou. Voltou para dentro de casa. Chorou mais um pouco. Passou dias com aquela tristeza. Estela tinha pouca idade e ainda não sabia que aquela a dor no peito, no futuro, ela aprenderia a chamar de luto.

[TEXTO INÉDITO]

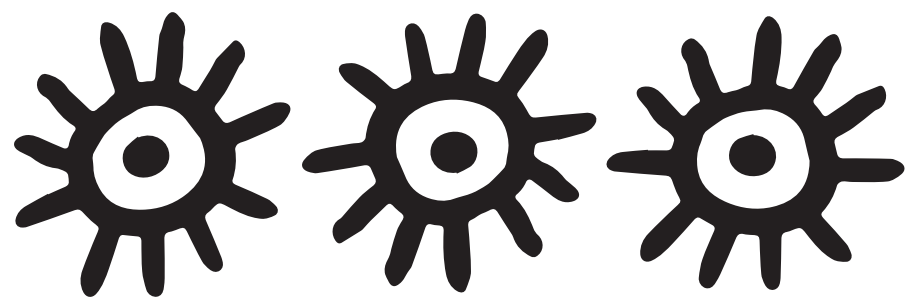

